\title{
Central nervous system cladosporiosis: An account of ten culture-proven cases
}

\author{
Nitin Garg, Indira B. Devi, Girish V. Vajramani, S. Nagarathna*, S. Sampath, B. A. Chandramouli, \\ A. Chandramuki*, S. K. Shankar** \\ Departments of Neurosurgery, "Neuromicrobiology and **Neuropathology, National Institute of Mental Health and Neurosciences, Bangalore \\ - 29, India
}

\begin{abstract}
Background: Central nervous system (CNS) cladosporiosis is a rare infection caused by Cladophialophora bantiana. It has varied presentation and poor outcome. Most of the available data in the literature are reviews of individual case reports. Objective: To describe the clinical, radiological and mycological features of 10 cases of $C$. bantiana managed at a single tertiary center. To analyze the various treatment options, factors associated with outcome, and to review the relevant literature. Materials and Methods: This is a retrospective study of 10 patients with CNS cladosporiosis managed at National Institute of Mental Health and Neurosciences from 1979 to 2006. It is a descriptive study. The case records were reviewed for clinical presentation, radiological features, management and outcome. Only those patients in whom the fungus could be isolated on culture were included in the study. Results: The age of the patients ranged from three to 42 years. Nine patients presented with features of space-occupying lesion and one patient with chronic meningitis. There were no specific clinical or radiological features. None of patients had impaired immune status. This infection presented as two pathomorphological forms - diffuse meningoencephalitis and focal abscesses. Burr hole tapping and excision are the surgical options. Both patients with burr hole tapping required excision of abscess subsequently. Two out of seven patients with abscess expired compared to all three patients with diffuse meningoencephalitis who expired. Recurrences occurred in four of the five patients following excision of the abscess. Combination antifungal treatment had better result than monotherapy. The outcome was poor with survival of only $50 \%$. Conclusions: Thorough microbiological examination is required to diagnose CNS infection caused by C. bantiana. The outcome is better in patients with abscess. Excision of the abscess followed by combination antifungal therapy results in better outcome. Close follow-up is required due to high risk of recurrence.
\end{abstract}

Key words: Cerebral abscess, Cladophialophora bantiana, cladosporiosis, fungal abscess, phaeohyphomycosis
Phaeohyphomycosis is an infection caused by a number of dematiaceous fungi, characterized by the basic development of dark colored filamentous hyphae in the invaded tissue. These exist in hyphal to yeast forms in the tissue. There are about 25 phaeoid fungal species identified as causing phaeohyphomycosis of which Cladophialophora bantiana (C. bantiana) is the most common species affecting humans. ${ }^{[1]}$ This fungus has a distinct neurotropism..$^{[2,3]}$ This is a rare fungal infection, the incidence of which has been increasing lately. ${ }^{[4]}$ This infection has two broad groups - one is disseminated systemic phaeohyphomycosis (DSP) wherein infection is disseminated throughout the body and the other is cerebral phaeohyphomycosis which is restricted to the central nervous system (CNS). ${ }^{[3]}$ While the former have associated decreased host immunity, this is not the case in the latter. The outcomes are poor with survival rates of $29-45 \% \cdot{ }^{[1]}$ Most of the data in the literature is a compilation of individual case reports. We have had the experience of treating cerebral lesions caused by $\mathrm{C}$. bantiana in 10 patients at the National Institute of Mental Health and Neurosciences. In this report, we analyze the clinical, radiological and mycological features, the factors responsible for poor outcome and review the relevant literature. To our knowledge, this is the largest study of cases from a single center.

\section{Materials and Methods}

This is a retrospective study. We reviewed the clinical records of patients with CNS cladosporiosis proven by growth of the fungus on culture. From 1979, when the first case was reported till 2006, there were 10 cases of CNS infection caused by C. bantiana. Of the 2160 cases of intracranial abscesses (bacterial, tubercular and fungal) managed during this period, 22 were fungal and seven of 
these were due to $\mathrm{C}$. bantiana. The remaining three were cases of diffuse meningoencephalitis due to this fungus. The medical records department at the National Institute of Mental Health and Neurosciences (NIMHANS) has case files stored and indexed. These were retrieved by the first author. The radiology of patients prior to
1994 is not available and the facts written in the file were used. Subsequent images were retrieved from the records department of the Neuroradiology department. The clinical data, radiological features, management and outcome in these 10 cases were analyzed in detail [Table 1].

\begin{tabular}{|c|c|c|c|c|c|c|c|}
\hline \multicolumn{8}{|c|}{ Table 1: Summary of cases } \\
\hline $\begin{array}{l}\text { Agel } \\
\text { Sex }\end{array}$ & Clinical features & $\begin{array}{l}\text { CT scan/ } \\
\text { angiogram }\end{array}$ & LP CSF & Operative findings & $\begin{array}{l}\text { Antifungal } \\
\text { agents }\end{array}$ & $\begin{array}{l}\text { Patho- } \\
\text { morphological } \\
\text { form }\end{array}$ & Outcome \\
\hline 37/M & $\begin{array}{l}\text { Rt hemiparesis } \\
-1 \text { month Altered } \\
\text { sensorium- } 2 \\
\text { days }\end{array}$ & $\begin{array}{l}\text { LCA - Parietal } \\
\text { mass }\end{array}$ & $\begin{array}{l}3500 \text { polys } \\
20 \text { mg\% glu } 220 \\
\text { mg } \% \text { proteins }\end{array}$ & Burr hole biopsy & $\begin{array}{l}\text { Not given } \\
\text { (diagnosed } \\
\text { postmortem) }\end{array}$ & $\begin{array}{l}\text { Diffuse meningo- } \\
\text { encephalitis with } \\
\text { cerebritis }\end{array}$ & Expired \\
\hline $32 / \mathrm{M}$ & $\begin{array}{l}\text { Psychotic } \\
\text { behavior - } 6 \\
\text { months } \\
\text { Left hemipareses } \\
\text { - } 2 \text { days }\end{array}$ & $\begin{array}{l}\text { RCA- } \\
\text { Suprasylvian } \\
\text { mass }\end{array}$ & $\begin{array}{l}500 \text { polys } \\
20 \mathrm{mg} \% \text { glu } \\
80 \mathrm{mg} \% \text { proteins }\end{array}$ & $\begin{array}{l}\text { Burr hole aspiration - } \\
10 \mathrm{ml} \\
\text { yellowish necrotic } \\
\text { material }\end{array}$ & $\begin{array}{l}\text { Not given } \\
\text { (diagnosed } \\
\text { postmortem) }\end{array}$ & $\begin{array}{l}\text { Diffuse meningo- } \\
\text { encephalitis with } \\
\text { cerebritis }\end{array}$ & Expired \\
\hline $42 / \mathrm{M}$ & $\begin{array}{l}\text { Left hemiparesis } \\
-8 \text { months } \\
\text { Headache and } \\
\text { fever - } 4 \text { months }\end{array}$ & $\begin{array}{l}\text { Extensive right } \\
\text { parieto-occipital } \\
\text { hypodense } \\
\text { areas with mild } \\
\text { hydrocephalus }\end{array}$ & $\begin{array}{l}720 \text { cells } 60 \% \\
\text { poly } 40 \% \text { lympho }\end{array}$ & - & $\begin{array}{l}\text { Not given } \\
\text { (diagnosed } \\
\text { postmortem) }\end{array}$ & $\begin{array}{l}\text { Diffuse meningo- } \\
\text { encephalitis with } \\
\text { cerebritis }\end{array}$ & Expired \\
\hline 20/M & $\begin{array}{l}\text { Raised ICT - } 4 \\
\text { months Altered } \\
\text { sensorium - } 8 \\
\text { days }\end{array}$ & $\begin{array}{l}\text { Multiple } \\
\text { right frontal } \\
\text { hypodense } \\
\text { ring-enhancing } \\
\text { lesions }\end{array}$ & $\begin{array}{l}375 \text { cells all } \\
\text { polys } 40 \mathrm{mg} \% \\
\text { glu } \\
54 \mathrm{mg} \% \text { proteins }\end{array}$ & $\begin{array}{l}\text { Craniotomy } \\
\text { and excision. } \\
\text { Multiloculated thick } \\
\text { walled abscess. } \\
\text { Rt VP shunt }\end{array}$ & $\begin{array}{l}\text { Amphotericin } \\
\text { B }\end{array}$ & Abscess & Expired \\
\hline $16 / \mathrm{M}$ & $\begin{array}{l}\text { Raised ICT - } 5 \\
\text { months }\end{array}$ & $\begin{array}{l}\text { Multiple } \\
\text { coalescing right } \\
\text { frontal lesions }\end{array}$ & $\begin{array}{l}2 \text { cells } \\
18 \mathrm{mg} \% \text { glu } \\
20 \mathrm{mg} \% \text { proteins }\end{array}$ & $\begin{array}{l}\text { Craniotomy and } \\
\text { excision. Re-explored } \\
\text { twice to achieve total } \\
\text { excision. }\end{array}$ & $\begin{array}{l}\text { Amphotericin } \\
B+5 \text { FC }\end{array}$ & Abscess & $\begin{array}{l}\text { Good. } 24 \\
\text { months FU }\end{array}$ \\
\hline 20/M & $\begin{array}{l}\text { Right } \\
\text { hemiparesis - } 10 \\
\text { days }\end{array}$ & $\begin{array}{l}\text { Left posterior } \\
\text { frontal } \\
\text { hypodense ring- } \\
\text { enhancing lesion }\end{array}$ & & $\begin{array}{l}\text { Stereotactic } \\
\text { aspiration Repeated } \\
\text { tapping. Craniotomy } \\
\text { and excision. Re- } \\
\text { explored for excision. }\end{array}$ & $\begin{array}{l}\text { Amphotericin } \\
B+5-F C\end{array}$ & Abscess & $\begin{array}{l}\text { Good. } 5 \\
\text { months FU }\end{array}$ \\
\hline $49 / \mathrm{M}$ & $\begin{array}{l}\text { Right } \\
\text { hemiparesis - } 2 \\
\text { months. } \\
\text { Raised ICP - } 1 \\
\text { month }\end{array}$ & $\begin{array}{l}\text { Two cystic } \\
\text { ring-enhancing } \\
\text { lesions in left } \\
\text { frontoparietal } \\
\text { region }\end{array}$ & - & $\begin{array}{l}\text { Craniotomy and } \\
\text { excision. Thick-walled } \\
\text { abscess. Yellowish } \\
\text { pus. }\end{array}$ & $\begin{array}{l}\text { Amphotericin } \\
\mathrm{B}+ \\
\text { Fluconazole }\end{array}$ & Abscess & $\begin{array}{l}\text { Good } \\
3 \text { months } \\
\text { FU }\end{array}$ \\
\hline $22 / \mathrm{M}$ & $\begin{array}{l}\text { Right } \\
\text { hemiparesis- } 2 \\
\text { months. Raised } \\
\text { ICP- } 1 \text { month }\end{array}$ & $\begin{array}{l}\text { Ring-enhancing } \\
\text { lesion left frontal } \\
\text { lobe }\end{array}$ & - & $\begin{array}{l}\text { Craniotomy and } \\
\text { excision. Repeated } \\
\text { tapping for } \\
\text { recollection. Re- } \\
\text { exploration and } \\
\text { excision. }\end{array}$ & $\begin{array}{l}\text { Amphotericin } \\
B+5-F C\end{array}$ & Abscess & $\begin{array}{l}\text { Expired due } \\
\text { to meningitis } \\
\text { and } \\
\text { ventriculitis }\end{array}$ \\
\hline $25 / M$ & $\begin{array}{l}\text { Raised ICT } \\
-1 \text { month Right } \\
\text { hemiparesis- } 5 \\
\text { days }\end{array}$ & $\begin{array}{l}\text { Right frontal } \\
\text { ring-enhancing } \\
\text { lesions }\end{array}$ & - & $\begin{array}{l}\text { Burr hole and } \\
\text { tapping followed } \\
\text { by craniotomy and } \\
\text { excision. }\end{array}$ & $\begin{array}{l}5-F C+ \\
\text { Itraconazole }\end{array}$ & Abscess & $\begin{array}{l}\text { Good } \\
3 \text { year FU }\end{array}$ \\
\hline 3/M & $\begin{array}{l}\text { Right } \\
\text { hemiparesis- } 5 \\
\text { months }\end{array}$ & $\begin{array}{l}\text { Left posterior } \\
\text { frontal multiple } \\
\text { coalescing } \\
\text { ring-enhancing } \\
\text { lesions }\end{array}$ & - & $\begin{array}{l}\text { Craniotomy and } \\
\text { excision. Re- } \\
\text { exploration and } \\
\text { excision after } 20 \text { days }\end{array}$ & Voriconazole & Abscess & $\begin{array}{l}\text { Good. } \\
3 \text { month FU }\end{array}$ \\
\hline
\end{tabular}

Rt=Right, Lt=Left, LCA=Left carotid angiogram, RCA=Right carotid angiogram, polys=polymorphs, lympho=lymphocytes, Glu= Glucose, 5-FC=5-Flucytosine, ICT=Intracranial tension, $\mathrm{FU}=$ follow-up, CSF analysis not done in last 5 cases 


\section{Results}

The age of the patients ranged from three to 42 years (median 23.5 years), seven of them being farmers. All the patients were males. Seven patients were farmers, one was a software engineer and one was a mill-worker.

The duration of symptoms ranged from 10 days to eight months (median three months). Nine patients presented with focal neurological deficits and raised intracranial pressure (ICP). One patient (Case 3) presented with chronic meningitis. Fever was present in only five patients. None of these patients had predisposing factors such as diabetes mellitus, chronic steroid therapy, tuberculosis, chronic immunosuppressive therapy or human immunodeficiency virus (HIV) infection. None of these patients had history of trauma or fungal skin lesions.

Computed tomography (CT) scan was done in all patients except in two who underwent angiogram prior to availability of CT scan. The mass was avascular in these two patients with features of mass effect on the angiogram. In all patients except one (Case 3), CT scan showed multiple coalescing ring-enhancing lesions with hypodense center with significant perilesional edema [Figure 1]. The lesions were located in the frontal lobe predominantly. In one patient (Case 3), the CT scan showed an ill-defined hypodensity in the right parietooccipital region with mild hydrocephalus. The CT picture was thought to be consistent with infarction. However, at autopsy, granular, necrotic and hemorrhagic lesions were seen in the frontoparietooccipital white matter extending to the basal ganglia and diencephalic nuclei. Necrotic tissue from this area submitted for fungal culture grew C. bantiana. Cerebrospinal fluid (CSF) analysis was done in five patients. It revealed evidence of significant pleocytosis with polymorph predominance in three patients. However, the fungus could be isolated from the CSF in only one patient

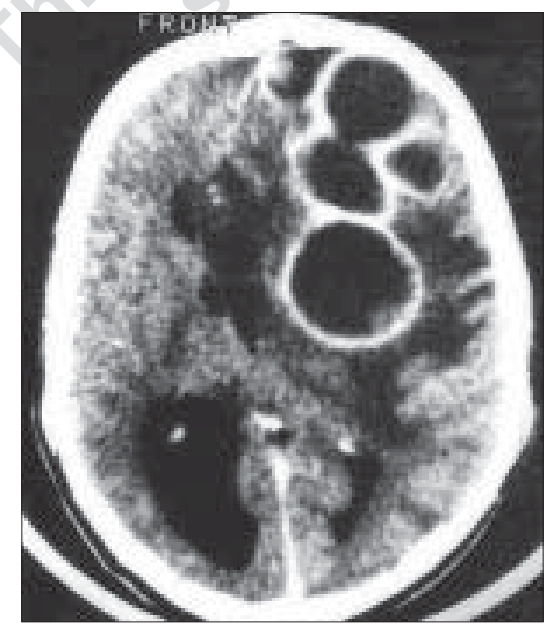

Figure 1: Computed tomography (CT) scan showing multiple coalescing ring-enhancing lesions with hypodense center with significant perilesional edema (Case 5) who had ventricular contamination during surgery for multiloculated lesion. Chest radiograph was normal in most of the patients. One patient had features of bronchiectasis and another had consolidation of the lung which resolved with antibiotics. None of the patients had CNS involvement as a part of disseminated systemic phaeohyphomycosis.

Burr hole tapping of abscess, excision or both were the surgical procedures performed in those with abscess. Burr hole tapping was done in four patients (Cases 1, 2, 6 and 9). In Cases 1 and 2, this was done prior to the CT era for diagnostic purposes. These were nonconclusive in both these patients. In Cases 6 and 9, burr hole tapping revealed yellowish brown, non-foul-smelling pus. Craniotomy and excision of abscess was done due to persistence of the abscess in spite of being on antifungal drugs and repeated tapping. Total excision of the abscess was done primarily in five patients (Cases $4,5,7,8,10$ ). Intraoperatively, these lesions had multiple loculi, with thick-walled capsule containing non-foul-smelling yellowish, viscid, inspissated purulent material. These patients had significant and early improvement in their neurological status. However, four patients of these five had recurrence of the abscess requiring repeat surgery [Figure 2]. The recurrence was early, within one month, in spite of being on antifungal therapy.

Microscopic examination of the wet mount preparation of this material (pus or necrotic tissue) revealed septate, darkly pigmented, brownish hyphae with many conidia free or attached to the sides. Following this, the samples were submitted on Sabouraud's dextrose agar (incubated at room temperature and at $37^{\circ} \mathrm{C}$ ). On the fifth day of incubation, olive green-colored colonies [Figure 3 ] appeared which turned to brown by the $15^{\text {th }}$ day. Lactophenol cotton blue preparation from these fungal colonies showed septate, darkly pigmented hyphae with chains of elliptical conidia attached [Figure 4]. The infection was poorly defined extensive necrotic lesion

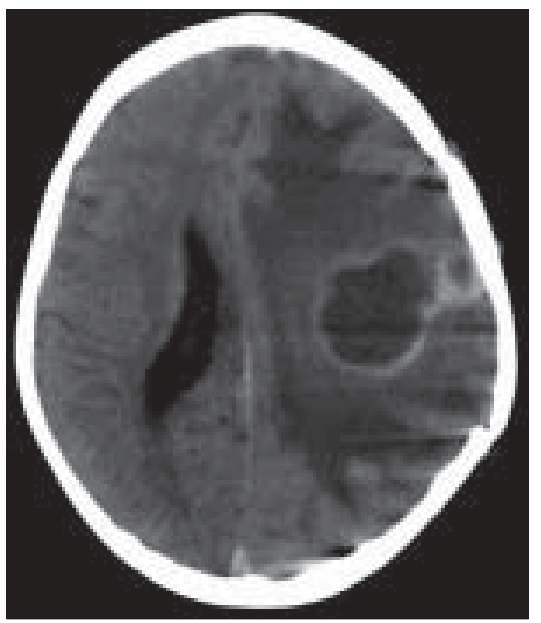

Figure 2: CT scan with recurrence of the lesion (Case 10) 


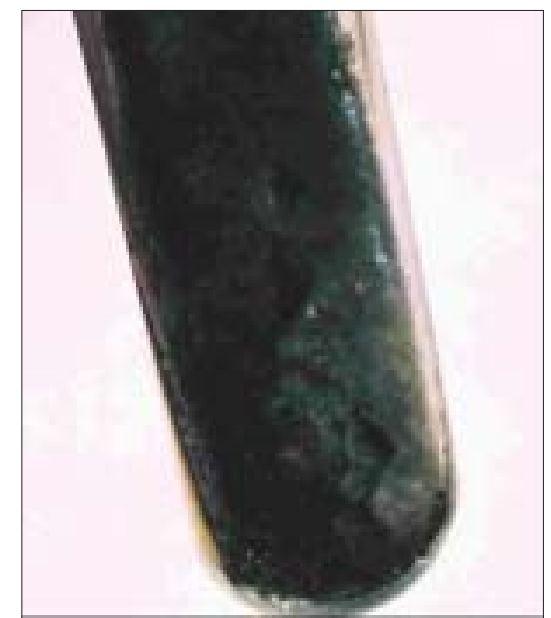

Figure 3: Culture of Cladophialophora bantiana on Sabouraud's dextrose agar showing olive-green colonies

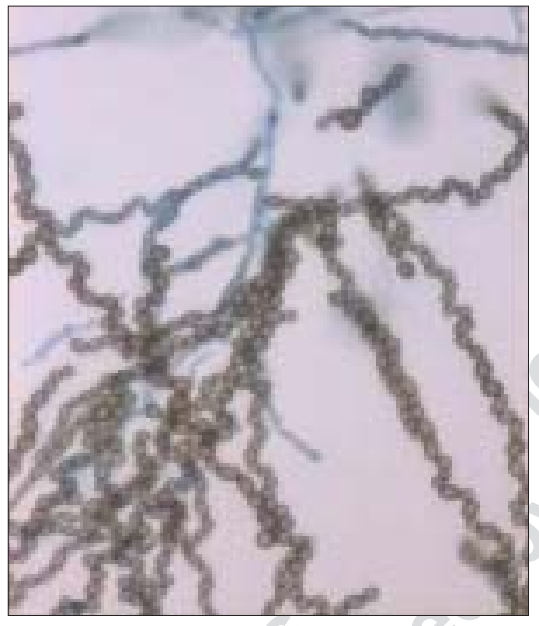

Figure 4: Lactophenol cotton blue preparation of culture of Cladophialophora bantiana under microscope $(40 \mathrm{x})$ showing conidiophore-bearing long partly branched chains of elliptical conidia.

in three cases (Cases 1, 2, 3). In these three patients, the diagnosis could be established only on the basis of autopsy. In the remaining cases, there was a well-formed abscess with thick capsule and good plane of cleavage (Cases 4 to 10).

Antifungal treatment was given in all those in whom diagnosis was established antemortem. Amphotericin B (Amp B) was the drug of choice in combination with other antifungals as 5-Flucytosine, fluconazole or itraconazole. Amphotericin B was given as monotherapy in one patient and in combination with other antifungals in others. One patient (Case 10) received voriconazole. This patient was only three years old. He was started on voriconazole due to our limited experience of using Amp B in such young patients. This patient had a recurrence after one month of total excision requiring repeat surgery. The response to voriconazole was good following excision. At three months' follow-up, there was no recurrence.

Five patients had good outcome following surgery and antifungal treatment. All the patients with good outcome had well-defined abscess which were excised. These patients received Amp B in combination with 5-Flucytosine or itraconazole or only voriconazole monotherapy. Five patients expired (Cases 1,2,3,4,8). In Cases 1-3, the diagnosis could not be established antemortem. These patients had diffuse meningoencephalitis with necrosis. The other two patients had abscesses which were excised. Case 4 was in poor neurological state on admission to the hospital and prior to surgery. He progressively worsened following surgery. Case 8 had ventricular contamination during surgery and developed ventriculitis subsequently. Follow-up is available in all patients who survived. The mean follow-up was 14 months (range three to 36 months).

\section{Discussion}

C. bantiana is a dematiaceous fungus with distinct neurotropism. It is ubiquitous in nature without any predilection for geographic location or race. This fungus, of a considerable taxonomical confusion, has recently been accommodated under the genus Cladophialophora, separated from the saprophytic Cladosporium species by having poorly differentiated conidiophores and unpigmented scars. ${ }^{[5]}$ It has been isolated from soil, bark, detritus, decaying lumber and from brick walls of a feed and seed warehouse. ${ }^{[1,6-9]}$ This causes deepseated phaeohyphomycosis (DSP) in humans. The exact mode of infection is not clear though inhalation of spores into the lung and subsequent colonization and hematogenous spread to the brain is a widely accepted mode. ${ }^{[10,11]}$ Lung has been described as the most common site of primary invasion,,$^{[1,9,12]}$ though these elements have been seldom isolated from the lung. ${ }^{[13]}$ Trauma has been implicated in three cases. ${ }^{[14,15]}$ Trauma results in implantation of these fungal elements in the skin resulting in cutaneous or subcutaneous infection which may disseminate subsequently. While disseminated phaeohyphomycosis is more common in individuals with underlying conditions resulting in immunodeficiencies, cerebral phaeohyphomycosis affects apparently normal hosts..$^{[1,3,16]}$ However, more cases of cerebral phaeohyphomycosis are being reported to be occurring in immunocompromised hosts as following transplants, ${ }^{[1,12,17-23]}$ and in patients on longterm steroid treatment. ${ }^{[24,25]}$ None of our patients had preexisting or associated illnesses resulting in impaired immune status. All of them had disease restricted to the CNS.

Clinical features The usual clinical features are hemiparesis, seizure, fever and raised intracranial tension (ICT). ${ }^{[3,9]}$ Similar presentation was seen in our patients. Lumbar puncture revealed pleocytosis with polymorphonuclear cell predominance in most of the 
patients. This is consistent with earlier reports. ${ }^{[26,27]}$ In the absence of contamination, the CSF is generally sterile. Even in the case reported by Bennet, ${ }^{[26]}$ of chronic meningitis caused by this fungus, the CSF was sterile on many occasions. The diagnosis was established only at autopsy when the pus from the base of the brain grew the fungus on culture. In our series, the fungus could be cultured from the CSF in only one patient. In this patient, the ventricle was inadvertently opened while excising the deeply situated fungal abscess resulting in contamination and ventriculitis. Similar complications leading to ventriculitis and death have been reported. ${ }^{[28,29]}$

CNS cladosporiosis generally manifests as brain abscess. $^{[1,16]}$ Rare presentations as meningitis ${ }^{[26,30]}$ and extensive meningoencephalitis ${ }^{[13,31]}$ have also been reported. The morphology of the infection by this organism may depend upon the immune status and immune response. ${ }^{[3]}$ Diffuse meningoencephalitis with extensive necrosis have been reported predominantly in immunocompromised patients. ${ }^{[13]}$ In the present series, two pathomorphological forms of phaeohyphomycosis were seen. None of these patients had disseminated systemic phaeohyphomycosis or immunocompromised.

Radiological features: The radiological features of CNS cladosporiosis are not characteristic. The CT scans show the lesion to be either well-defined or poorly defined as described above. Well-defined lesions may be single ${ }^{[32]}$ or multiple conglomerate ring-enhancing ${ }^{[33]}$ with perilesional edema. It is not possible to differentiate bacterial or tubercular abscess ${ }^{[34]}$ from cladosporium abscess. Occasionally, the edema surrounding may be disproportionate to the size of the lesions. These abscesses are usually hemispheric, affecting the white matter. ${ }^{[13]}$ Similar CT findings were observed in our patients. There are reports of involvement of the choroids plexus, thalamus, diencephalons, cerebellum and brainstem..$^{[13,27,35-38]}$ Chest radiographs were normal in the majority of our patients.

Treatment: The most important factor that determines cure is the pathomorphological type of the fungal lesion. The surgical options for abscess include stereotactic biopsy and aspiration, ${ }^{[25]}$ burr hole and tapping ${ }^{[1]}$ and excision. ${ }^{[1,9,34]}$ Burr hole and tapping is inferior to excision. ${ }^{[1,25]}$ These patients may not have definitive diagnosis on aspiration (Cases 1 and 2) or may have significant residue requiring multiple attempts at aspiration (Cases 6, 9). The aspirate is also thick preventing adequate decompression. Both the patients who underwent multiple tappings subsequently required craniotomy and excision of the abscess due to persistence of lesion. Excision in cases with well-defined abscess helps in reducing the edema, reduction of the disease load and better response to antifungal therapy. ${ }^{[3]}$ Recurrences were common in spite of attempted total excision of the abscess. Re-excision was done in cases of residual or recurrences in spite of being on antifungal treatment (Cases 5, 6, 8,10). Importantly, all these recurrences were early, within one month postoperatively. Hence it is important to keep these patients on close clinical and radiological follow-up. It is important to avoid contaminating the CSF spaces, especially the ventricle. Once the infection becomes widespread, the outcome is fatal despite aggressive surgical management and antifungal therapy as noticed in Case 7.

The efficacy of various antifungal agents is not clearly established in humans. Amphotericin B, flucytosine, itraconazole and newer triazoles such as voriconazole and posaconazole have all been used with limited success in these patients. ${ }^{[39-42]}$ These fungi may have innate or acquired resistance to Amphotericin B. ${ }^{[3]}$ In our series, Amphotericin B was the most commonly used antifungal agent (Cases 4-8). This was used either singly or in combination with 5-Flucytosine or fluconazole. The results were mixed. The patient who received only Amphotericin $B$ following excision of the abscess died (Cases 4). Of the four patients who received Amphotericin B in combination with other antifungals, three cases had a good response and one patient expired (Case 8). Al-Abdely et al. ${ }^{[41]}$ in their experimental study on mouse showed that Amphotericin B prolonged survival but did not lower the brain counts of the fungus significantly. Dixon and Pollock too found this drug to have a modest effect on the survival at higher doses. ${ }^{[42]}$ Hence a combination therapy may be more beneficial as seen in three of our cases. Amongst the various antifungals available for treatment, new triazoles have shown promising results in animal studies and in case reports. Amongst the triazoles, fluconazole is not effective in cerebral phaeohyphomycosis. ${ }^{[41]}$ Recently, more cases of successful treatment of cladosporium abscess are being reported with the use of voriconazole..$^{[18,39,40]}$ Experimental studies in murine models have shown the best response with newer triazole posaconazole. ${ }^{[41]}$

Mortality: Central nervous system cladosporiosis is associated with high mortality rates with survival up to $29-45 \% \cdot{ }^{[1,16,27]}$ In the present series, the final outcome was poor with only $50 \%$ survival rate. All three patients with diffuse meningoencephalitis with cerebritis expired. Two patients out of seven with cerebral abscess expired. One of them was in poor neurological status prior to surgery and the other developed ventriculitis and meningitis.

\section{Conclusion}

CNS infection caused by Cladophialophora bantiana, may present as well-defined abscess or poorly demarcated 
cerebritis with extensive necrotic lesions. There are no specific clinical or radiological features to suggest the diagnosis. Hence a thorough microbiological analysis is required to diagnose this infection. Excision of the abscess followed by antifungal therapy may improve the outcome. Amphotericin B has a limited efficacy when used alone and may be used in combination with other antifungals as 5-Flucytosine, itraconazole or newer triazoles such as voriconazole to improve the results. Diffuse meningoencephalitis, poor neurological state and associated meningitis and ventriculitis are associated with poor outcomes.

\section{Acknowledgments}

The authors would like to acknowledge the help and inspiration of Sastry Kolluri, Professor and Ex-Head of Department of Neurosurgery, NIMHANS.

\section{References}

1. Revankar SG, Sutton DA, Rinaldi MG. Primary central nervous system phaeohyphomycosis: A review of 101 cases. Clin Infect Dis 2004;38:20616.

2. Sepkowitz K, Armstrong D. Space occupying fungal lesions. In: Scheld WM, Whitley RJ, Durack DT, editor. Infections of the central nervous system. $2^{\text {nd }}$ ed. Lippincott-Raven Publishers: Philadelphia; 1997. p. 741-62.

3. Cooper CR Jr. Deep phaeohyphomycosis. I n: Merz WG, Hay RJ, editors. Topley and Wilson's Microbiology and Microbial Infections- Medical Mycology. $10^{\text {th }}$ ed. Hodder Arnold Publishers: London; 2005. p. 73948 .

4. Cooper CR Jr. New and emerging pathogens: What is a lab to do? In: Calderone RA, Cihlar RL, editors. Fungal pathogenesis. Marcel Dekker: New York; 2002. p. 751-7.

5. Jayakeerthi SR, Dias M, Nagarathna S, Anandh B, Mahadevan A, Chandramukhi A. Brain abscess due to Cladophialophora bantiana. Indian J Med Microbiol 2004;22:193-5.

6. Dixon DM, Shadomy HJ, Shadomy S. Isolation of Cladosporium trichoides from nature. Mycopathologia 1977;62:125-7.

7. Dixon DM, Shadomy HJ, Shadomy S. Dematiaceous fungal pathogens isolated from nature. Mycopathologia 1980;70:153-61.

8. Espinel-Ingroff A, Kerkering TM, Shadomy HJ. Isolation of dematiaceous pathogenic fungi from a feed and seed warehouse. J Clin Microbiol 1982;15:714-9.

9. Kantarcioglu AS, de Hoog GS. Infections of the central nervous system by melanized fungi: A review of cases presented between 1999 and 2004. Mycoses 2004;47:4-13

10. Dixon DM, Merz WG, Elliott HL, Macleay S. Experimental central nervous system phaeohyphomycosis following intranasal inoculation of Xylohypha bantiana in cortisone treated mice. Mycopathologia 1987;100:145-53.

11. Borges MC Jr, Warren S, White W, Pellettiere EV. Pulmonary phaeohyphomycosis due to Xylohypha bantiana. Arch Pathol Lab Med 1991;115:627-9.

12. Baddley JW, Salzman D, Pappas PG. Fungal brain abscess in transplant recipients: Epidemiologic, microbiologic and clinical features. Clin Transplant 2002;16:419-24.

13. Emmens RK, Richardson D, Thomas D, Hunter S, Hennigar RA, Wingarg JR, et al. Necrotizing cerebritis in an allogenic bone marrow transplant recipient due to Cladophialophora bantiana. J Clin Microbiol 1996;34:1330-2.

14. Duque O. Meningo-encephalitis and brain abscess caused by Cladosporium and Fonsecaea. Review of the literature, report of two cases, and experimental studies. Am J Clin Pathol 1961;36:505-17.
15. Kim RC, Hodge CJ Jr, Lamberson HV Jr, Weiner LB. Traumatic intracerebral implantation of Cladosporium trichoides. Neurology $1981 ; 31: 1145-8$

16. Filizzola MJ, Martinez F, Rauf SJ. Phaeohyphomycosis of the central nervous svstem in immunocompetent hosts: Report of a case and review of the literature. Int J Infect Dis 2003;7:282-6.

17. Silviera ER, Resende MA, Mariano VS, Coura WA, Alkmim LD, Vianna LB, et al. Brain abscess caused by Cladophialophore (Xylophora) bantiana in a renal transplant patient. Transpl Infect Dis 2003;5:104-7.

18. Trinh JV, Steinback WJ, Schell WA, Kurtzberg J, Giles SS, Perfect JR. Cerebral phaeohyphomycoses in an immunodeficient child treated medically with combination antifungal therapy. Med Mycol 2003;41:33945 .

19. Keyser A, Schmid FX, Linde HJ, Merk J, Birnbaum DE. Disseminated Cladophialophora bantiana infection in a heart transplant recipient. J Heart Lung Transplant 2002;21:503-5.

20. Walsh TJ, Groll AH. Emerging fungal pathogens: evolving challenges to immunocompromized patients for the twenty-first century. Transpl Infect Dis $1999 ; 1: 247-61$.

21. Osiyemi OO, Dowdy LM, Mallon SM, Cleary T. Cerebral phaeohyphomycosis due to a novel species: Report of a case and review of literature. Transplantation 2001;71:1343-6.

22. Gupta SK, Manjunath PK, Sharma BS, Khosla VK, Kak VK, Minz M, et al. Brain abscess in renal transplant receipients: Report of three cases. Surg Neurol 1997;48:284-7.

23. Takei H, Goodman JC, Powell SZ. Cerebral phaeohyphomycosis caused by Cladophialophora bantiana and Fonsecaea monophora: Report of three cases. Clin Neuropathol 2007;26:21-7.

24. Salem FA, Kannangara DW, Nachum R. Cerebral chromomycosis. Arch Neurol 1983;40:173-4.

25. Raut A, Muzumdar D, Narlawar R, Nagar A, Ahmed N, Hira P. Cerebral abscess caused by Cladosporium bantianum infection: Case report. Neurol Med Chir (Tokyo) 2003;43:413-5.

26. Bennett JE, Bonner H, Jennings AE, Lopez RI. Chronic meningitis caused by Cladosporium trichoides. Am J Clin Pathol 1973;59:398407.

27. Dixon DM, Walsh T.J, Merz WG, McGinnis MR. Infections due to Xylohypha bantiana (Cladosporium trichoides). Rev Infect Dis 1989;11:515-25

28. Dastur HM, Chaukar AP, Rebello MD. Cerebral chromoblastomycosis due to Cladosporium trichoides (Bantianum). I. (A review and case report). Neurol India 1966;14:1-5.

29. Desai SC, Bhatikar ML, Mehta RS. Cerebral chromoblastomyeosis due to Cladosporium trichoides (Bantianum). II. (Mycopathologic investigation of brain and skin involvement). Neurol India 1966;14:6-18.

30. Banerjee TK, Patwari AK, Dutta R, Anand VK, Chabra A. Cladosporium bantianum meningitis in a neonate. Indian J Pediatr 2002;69:721-3.

31. Chandramukhi A, Ramadevi MG, Shankar SK. Cerebral cladosporiosis: A neuropathological and microbiological study. Clin Neurol Neurosurg $1983 ; 85: 245-53$

32. Goel A, Satoskar A, Desai AP, Pandya SK. Brain abscess caused by Cladosporium trichoides. Br J Neurosurg 1992;6:591-3.

33. Roche M, Redmond RM, O'Neill S, Smyth E. A case of multiple cerebral abscesses due to infection with Cladophialophora bantiana. J Infect 2005;51:e285-8.

34. Nadkarni TD, Goel A, Shenoy A, Karapurkar AP. Cladosporium bantianum (trichoides) infection of the brain. J Postgrad Med $1993 ; 39: 43-4$

35. Heney C, Song E, Kellen A, Raal F, Miller SD, Davis V. Cerebral phaeohyphomycosis caused by Xylohypha bantiana. Eur J Clin Microbiol Infect Dis 1989;8:984-8.

36. Palaoglu S, Sav A, Basak T, Yalcinlar Y, Scheithauer BW. Cerebral phaeohyphomycosis. Neurosurgery 1993;33:894-7.

37. Sekhon AS, Galbraith J, Mielke BW, Garg AK, Sheehan G. Cerebral phaeohyphomycosis caused by Xylohypha bantiana, with a review of literature. Eur J Epidemiol 1992;8:387-90.

38. Sujith Kumar JS, Dugar M, Chacko G. Cerebral phaeohyphomycosis presenting as an intraventricular mass. Neurol India 2006;54:102-3.

39. Fica A, Diaz MC, Luppi M, Olivares R, Saez L, Baboor M, et al. Unsuccessful treatment with voriconazole of a brain abscess due to 
Cladophialophora bantiana. Scand J Infect Dis 2003;35:892-3.

40. Lyons MK, Blair JE, Leslie KO. Successful treatment with voriconazole of fungal cerebral abscess due to Cladophialophora bantiana. Clin Neurol Neurosurg 2005;107:532-4.

41. Al-Abdely HM, Najvar LK, Bocanegra R, Graybill JR. Antifungal therapy of experimental cerebral phaeohyphomycosis due to Cladophialophora bantiana. Antimicrob Agents Chemother 2005;49:1701-7.

42. Dixon DM, Polack A. In vitro and in vivo drug studies with three agents of central nervous system phaeohyphomycosis. Chemotherapy $1987 ; 33: 129-40$.

Accepted on 13-06-07

Source of Support: Nil, Conflict of Interest: None declared.

\section{Author Help: Sending a revised article}

1) Include the referees' remarks and point to point clarification to those remarks at the beginning in the revised article file itself. In addition, mark the changes as underlined or coloured text in the article. Please include in a single file

a. referees' comments

b. point to point clarifications on the comments

c. revised article with text highlighting the changes done

2) Include the original comments of the review ers/editor with point to point reply at the beginning of the article in the 'Article File'. To ensure that the reviewer can assess the revised paper in timely fashion, please reply to the comments of the referees/editors in the following manner.

- There is no data on follow -up of these patients.

Authors' Reply: The follow up of patients have been included in the results section [Page 3, para 2]

- Authors should highlight the relation of complication to duration of diabetes.

Authors' Reply: The complications as seen in our study group has been included in the results section [Page 4, Table] 